\title{
STUDY ON VISUAL COMPLEXITY USING RMS CONTRAST STATISTICS IN STREETSCAPE COMPOSITION IN ALGERIA AND JAPAN \\ 日本とアルジェリアの街路景観構成における RMS コントラストを利用した 視覚的な複雑性に関する研究
}

\section{Lemya KACHA EPE MANSOURI* , Naoji MATSUMOTO** , Andre CAVALCANTE*** and Ahmed MANSOURI****}

カシャエペマンソウリレミヤ，松本直司，カヴァルカンチアンドレ，マンソウリアハメッド

This study aims to explore visual complexity in streetscape composition using a new method of measurement based on RMS contrast information. The dataset was composed of 74 streetscape images, taken in Algeria and Japan in daytime and nighttime. The evaluation and analysis covered two phases: (1) the subjective quantification of visual complexity using factor analysis and ranking method. (2) The visual complexity measurement based on RMS contrast statistics of streetscape images. The results showed a positive correlation between the subjective ranking of complexity in streetscape images and the proposed measure of visual complexity " $\alpha$ ". This correlation was high in daytime streetscapes and moderate in nighttime streetscapes. The sensitivity to complexity was higher in Algerian participants compared to Japanese participants.

Keywords: Visual Complexity, Cognitive appraisal, RMS, Image contrast 視覚的複雑, 認知的評価, RMS, イメージ・コントラスト

\section{Introduction}

As channels along which pedestrians move, streets received multiple interpretations in different schools of urban design. Some architectural historians defined streets as enclosed three-dimensional spaces between lines of adjacent buildings ${ }^{1}$. Typo-morphological school defined streets morphologically as the product of the spread of settlements, providing a framework for the distribution of land and giving access to individual plots ${ }^{2}$. Anthropological interpretation defined the concept of street as a physical entity seen as a more or less narrow and linear urban space lined by buildings, found in settlements and used for circulation and other activities ${ }^{3)}$.

The present study focuses on the complexity that refers to visual richness in streetscape. This complexity depends on the variety of street elements, types of buildings, amount of details, street furniture and signage as well as human activity. Because of research feasibility and data availability, the idea behind this study was to explore visual complexity in selected streets from different architectural and urban contexts in Algeria and Japan. Streets in Algerian cities have a mosaic of typologies generated by a superposition and juxtaposition of diverse urban patterns, such as Ottoman, French colonial and vernacular ${ }^{4)}$. In Japan, streets are generally characterized by an ephemera of elements attached to the buildings and an intense human activity ${ }^{5)}$.

Visual complexity is generated from the superposition of different profiles within a streetscape. These profiles include the street space, architectural variety of buildings, street elements like signage and furniture, human activity, trees, etc. The complexity generated through the connectedness of these profiles is the theme of the present study (Fig. 1).

\section{Aims and scope}

Affective appraisal of visual compositions is known to be strongly influenced by their degrees of complexity. How humans perceive and decide that a scene " $\mathrm{A}$ " is more complex than a scene " $\mathrm{B}$ " is yet to be understood. The analysis in this paper is focused on streetscape images. In such built environments, sensory overload caused by excessive complexity can influence the cognitive responses of pedestrians and their behavior. The main aim of this research is to analyze how contrast can influence the perception of visual

\footnotetext{
* Ph. D. Candidate, Graduate School of Engineering, Nagoya Institute of Technology,

名古屋工業大学大学院工学研究科 博士後期課程・工修 M. Eng.

** Prof., Graduate School of Engineering, Nagoya Institute of Technology, Dr. Eng.

*** Ph. D. Candidate, Graduate School of Information Science, Nagoya University, M. Eng.

**** Technical Assistant, Graduate School of Engineering, Nagoya Institute of Technology,

名古屋工業大学大学院工学研究科 教授·工博 Dr. Eng.

名古屋大学大学院情報科学研究科 博士後期課程 $\cdot$ 工修

名古屋工業大学大学院工学研究科 技術補佐員・博士 (工学)
} 
complexity in the composition of different streetscapes using RMS contrast measures. This can help in predicting subjective judgments of complexity in streetscape images.

The scope of this study refers to the introduction of a physical measure of visual complexity " $\alpha$ " in streetscapes based on RMS contrast statistics. The measurement works quite independently of environmental light conditions so that it can be used for daytime and nighttime streetscapes. This estimation can contribute in understanding the context of urban planning and design. That is to say: the quantification of sensory overload and the management of affective appraisal. It can also contribute in robot vision studies. For instance: environment understanding, situational awareness and decision making.

\section{Literature review}

Generally, subjective complexity is defined as the complexity of a composition as perceived by an external observer ${ }^{6)}$. In order to measure subjective complexity, some studies tried to quantify complexity of the stimuli by asking participants to rate scenes on the basis of a general complexity scale ${ }^{7,8)}$. Other studies collected ratings from participants on different scales of complexity and transformed them into a single measure 9,10$)$.

Physical or objective complexity is defined as the intrinsic complexity of a composition, independent from an external observer. The analysis of physical complexity is related to the level in which the streetscape is perceived. Low-level of perception is related to edges and texture while high-level perception is related to objects and scene recognition. Several studies attempted to derive objective measures of complexity by analyzing different aspects that covered: (1) irregularity and amount of elements disposition ${ }^{11)}$, (2) number of segments constituting random polygons ${ }^{12)}$, (3) checkerboard grain $^{13)},(4)$ order and disorder using Fourier transform ${ }^{14,15)},(5)$ entropy of pixel intensities ${ }^{16)}$, etc.

The present paper is related to the relationship between image contrast and visual complexity. There exist several measures of contrast such as the well-known Weber Contrast, Michelson contrast and RMS contrast. The latter represents the most reliable ${ }^{17)}$ and the more commonly used measure to quantify the details of an image in image processing systems ${ }^{18,19)}$.

\section{Area of the study}

Because of data availability and previous experience in the subject, authors selected Algeria and Japan as the main areas of this study. Nonetheless, lack of resources and time limits prevented the authors from covering a large number of cities in both countries.

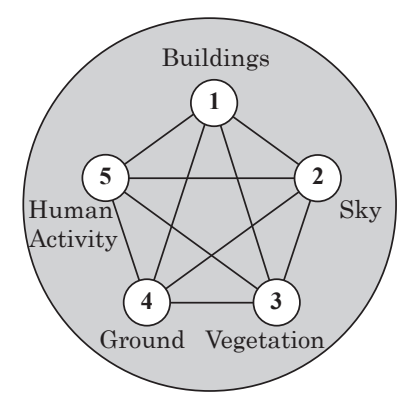

Fig. 1 Conceptual composition of the streetscape system
To avoid misleading generalization of the results that will issue from this study, authors based the collection of streetscape images on the idea of selecting two cities from each country in which the data collection would be feasible. Since this research is focused on streetscape composition (Fig. 1), the size and scale of each city were not considered as the primary and basic criterions. The way of discerning information from the perceived streetscape, according to human scale, is the orientation of this research.

Streetscape images were collected from (1) Tokyo and Batna cities because they offer different urban landscapes with aspects of modernity. (2) Kyoto and Al-Kantara cities because they include more traditional built environments.

In Tokyo, streetscape images were shot in the districts of Shibuya, Harajuku and Meguro. Shibuya is known as a center of Information Technology in Japan with streets full of fashion stores, restaurants and department stores. Harajuku streets include many landmarks, small fashion stores, fast food restaurants and so forth. Meguro represents a residential district with hilly landscape, situated in the southwestern part of Tokyo. Streetscape images collected in Kyoto city were shot in Gion, which is a preserved historic district in Higashiyama Ward. Its Architecture is mainly traditional and dates back to Edo period.

In Batna city, which is located on the high plains of eastern Algeria, streetscape images were collected in the "Stand" district. This district was mainly built for French colons during the colonial period. It is characterized morphologically by an orthogonal grid where straight streets define a series of regular urban blocks. Streetscape images collected in the town of Al-Kantara, located in the north of Biskra prefecture, were taken in "village rouge" and "village Blanc". The Architecture in these areas is mainly vernacular with few French colonial buildings.

\section{Research design}

This study attempted to explore complexity in the visual composition of streetscapes according to two main phases (Fig.2):

(1) The first phase consists in the quantification of the cognitive features related to visual complexity as seen by Japanese and Algerian participants. It covered: (A) Typological categorization using cluster analysis. (B) Cognitive appraisal using factor and cluster analyses. And (C) Complexity ranking using $C$-score.

(2) In the second phase, how contrast can influence the perception of visual complexity was explored using RMS contrast information of streetscape images. This phase covered: (1) Image contrast mapping using RMS contrast of luminance. And (2) Physical measures of visual complexity $\alpha$.

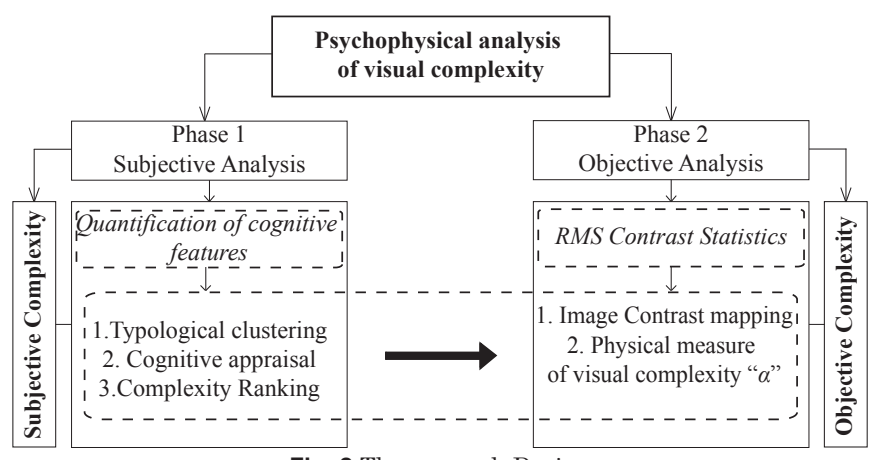

Fig. 2 The research Design 

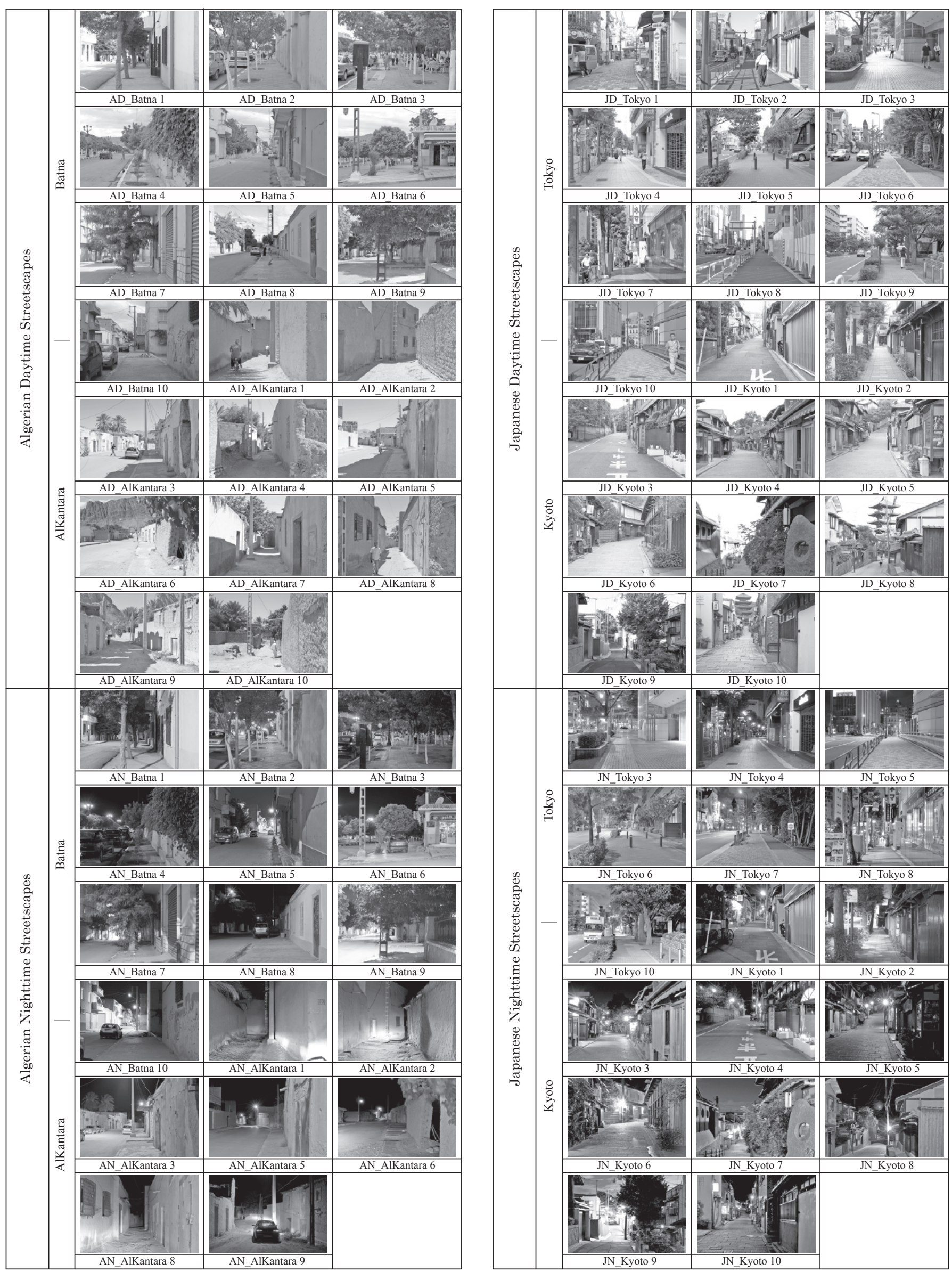

Fig.3 Streetscape images within the dataset 


\subsection{Collection of streetscape images}

The dataset used in this study was composed of 74 streetscape images. 37 images were shot in Al-Kantara and Batna cities. The other 37 images were taken in the cities of Kyoto and Tokyo (Fig. 3). Within the dataset, 40 images were acquired in daytime and 34 images in nighttime using a digital camera Nikon D300S with Nikkor lens system AF-S DX 35mm f/1.8G. All images were taken during summer season in two phases. The first phase was done in Algeria between the $17^{\text {th }}$ and the $19^{\text {th }}$ of June 2010 . The second phase was done in Japan between the $4^{\text {th }}$ and the $5^{\text {th }}$ of August 2010 (Tab. 1). The camera was fixed on a tripod in order to avoid artifacts caused by camera shaking (Fig. 4). All images were shot from the right side of each street to avoid heterogeneity in the vision fields. The image resolution was $4288 \times 2848$ pixels with a quality of $14 \mathrm{bits} /$ pixel. The original set of images was converted to JPEG format using Nikon ViewNx 2 software, with "Highest Compression Ratio" settings. For the evaluation done by the participants, original images in the format described above were used. For RMS contrast analysis, the images were transformed to grayscales and resampled to $1072 \times 712$ pixels.

\subsection{Data categorization}

Eight students from Nagoya Institute of Technology were asked to seek possible typological similarities among the images of the dataset, which were presented in a printed CMYK format (Fig.6.a). Object based classification was applied to measure the perceived similarity of each image with every other image within the dataset. A free classification approach was used, in which participants were free to cluster the different streetscape images according to their own personal criterions of appearance. The average number of clusters was six. Given a dataset of $\mathrm{N}$ items, where $\mathrm{N}=74$, authors generated $\mathrm{N}$ x N similarity matrix using a Microsoft Excel Macro. Using SPSS 11.0 Software, hierarchical clustering based on Ward method helped in defining six groups of streetscape images within the dataset. These clusters emerged from two main clusters that have the biggest distance (Fig. 5).

\section{Cognitive analyses of visual complexity}

\subsection{Experiment}

\subsubsection{Participants}

Two different categories of participants were involved in this study. The first category included 15 Japanese students in the department of architecture of Nagoya institute of technology (seven males and eight females). Their average age was 23 years old. The second category was composed of 15 Algerian participants (11 males and four females). Five of them were students in Architecture at Batna University. The other ten participants were architect practitioners in Batna city. Their average age was 25 years old.

\subsubsection{Procedure}

The evaluation of the dataset was conducted first in Japan with 15 Japanese participants in September 2011. In December of the same year, this experiment was conducted again in Algeria with 15 Algerian participants. Images in the dataset were presented in RGB color model using a large high resolution display Dell UltraSharpTM 3008WFP 760 (Fig 6.b). The distance between each participant and the display was about $80 \mathrm{~cm}$. Authors explained
Table 1 Collected Streetscape Images

\begin{tabular}{rcccc}
\hline Country & Period & Category & Number & Rate (\%) \\
\hline \multirow{2}{*}{ Algeria } & \multirow{2}{*}{ June 2010 } & Algerian Dayscape & 20 & 27 \\
& & Algerian Nightscape & 17 & 23 \\
\multirow{2}{*}{ Japan } & August 2010 & Japanese Dayscape & 20 & 27 \\
& & Japanese Nightscape & 17 & 23 \\
\hline & Total & & 74 & 100 \\
\hline
\end{tabular}

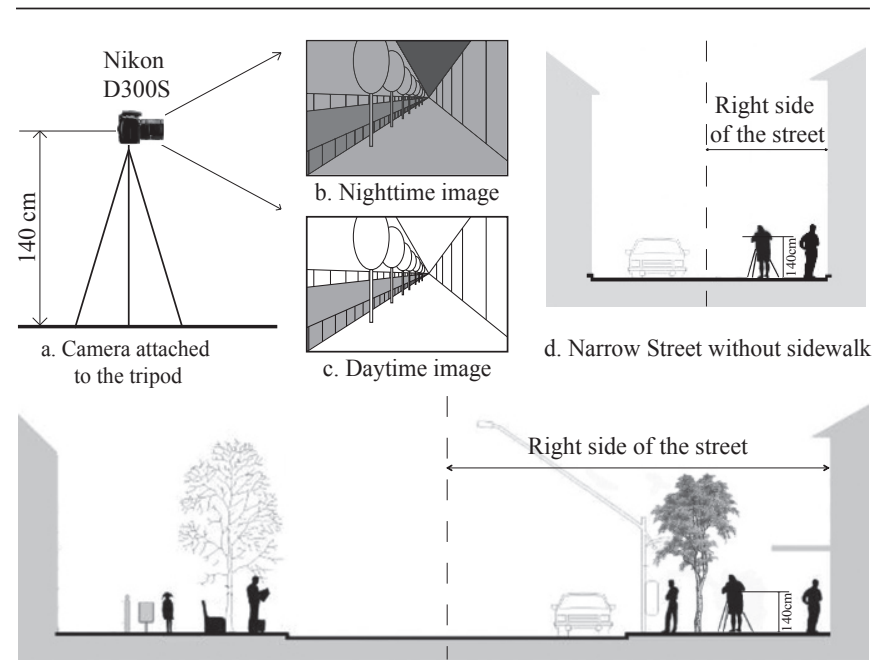

e. Wide Street with sidewalks

Fig. 4 Data collection method

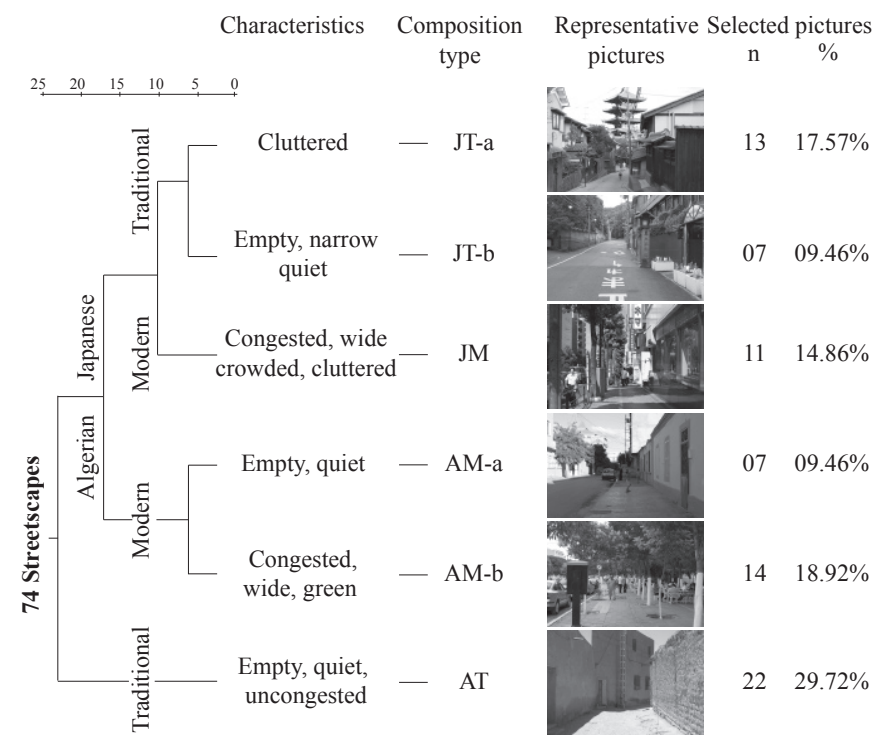

Fig.5 Typological clustering of all streetscapes

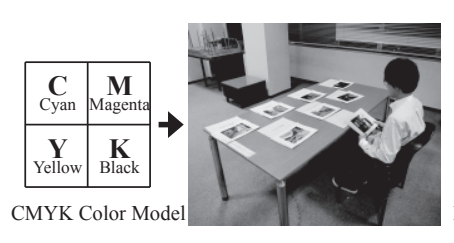

a. CMYK format

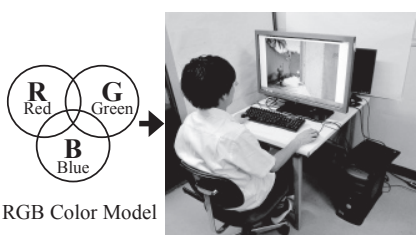

b. RGB format
Fig. 6 Participant evaluating Streetscape images in CMYK and RGB formats

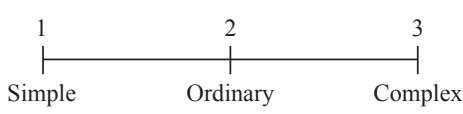

Fig.7 Complexity ranking scale 
the aim of the experiment to the participants and asked each one of them to estimate the visual complexity of each streetscape image by considering it as a whole interacting system of connected elements and patterns. Each participant was asked:

(1) First, to divide the dataset into three different groups on the basis of a general three-point scale of complexity "simple, ordinary, complex" (Fig. 7).

(2) Second, to rate the images within each group according to an increasing order of complexity from 1 to 74 . Several previous studies opted for a general three-point scale of evaluation in the analysis of urban scenes or landscapes. In this research, the reason behind the choice of this type of scales is the fact that this research does not rely only on a cognitive psychometric analysis. It attempts also to analyze the possible correlation between a subjective estimation of complexity within a streetscape image as seen by humans, and its physical estimation as a property of this image. Working on a scale of five or seven points might negatively influence the feasibility of this correlation.

\subsection{Statistical description of the dataset}

\subsubsection{Sample of participants}

Thirty participants voluntarily took part in the experiment as described in the procedure. Five Japanese participants (three males and two females) and five Algerian male participants were excluded from the analysis because their distribution rates were very low, which made the data commonness very low compared to other participants. Table 2 shows a description of the gender and countries of the chosen participants. The complexity ranking of the whole sample of 20 participants had a mean value of 2.07 and a standard deviation of 0.76 . Histograms in Figure 8 show a similarity among complexity rating distributions for male, female, Algerian and Japanese participants. Despite this similarity, complexity rating distributions were negatively skewed for all the histograms related to participants. With regard to kurtosis, coefficients showed that all distributions were platykurtic.

Table 2 Descriptive Statistics of sample participants

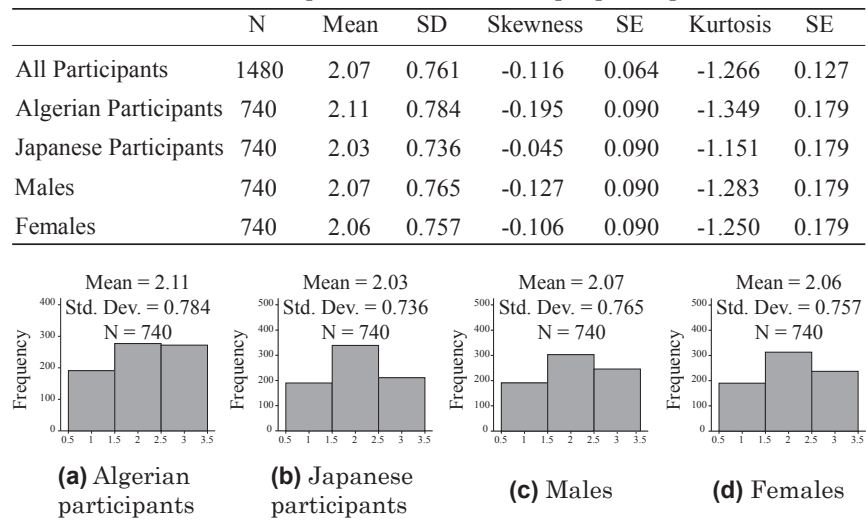

Fig. 8 Complexity histograms of sample participants

\subsubsection{Sample of streetscapes}

In order to analyze the sample of streetscape images separately, authors divided them into six groups. That is to say:

(a) Algerian streetscapes (Fig. 9.a), (b) Japanese streetscapes (Fig. 9.b), (c) Algerian daytime streetscapes (Fig. 9.c), (d) Japanese daytime streetscapes (Fig. 9.d), (e) Algerian nighttime streetscapes (Fig. 9.e) and (f) Japanese Nighttime streetscapes (Fig. 9.f). Analyzing the complexity score distribution in each group revealed some differences that are reflected in the descriptive statistical data included in table 3. Algerian and Japanese visual stimuli were quite different. The complexity score distributions of Algerian streetscape images (both daytime and nighttime) tended towards low values. They were platykurtic and positively skewed, which reflects the simplicity of Algerian visual stimuli. Contrarily, complexity ratings of Japanese streetscape images (both daytime and nighttime) tended towards higher values. They were platykurtic and negatively skewed, which means that Japanese visual stimuli were more complex.

Table 3 Descriptive Statistics of sample streetscapes

\begin{tabular}{lccccccc}
\hline & $\mathrm{N}$ & Mean & SD & Skewness & SE & Kurtosis & SE \\
\hline All streetscapes & 1480 & 2.07 & 0.761 & -0.116 & 0.064 & -1.266 & 0.127 \\
Algerian streetscapes & 740 & 1.71 & 0.718 & 0.487 & 0.090 & -0.953 & 0.179 \\
Algerian daytime str. & 400 & 1.64 & 0.690 & 0.606 & 0.122 & -0.756 & 0.243 \\
Algerian nighttime str. 340 & 1.80 & 0.743 & 0.345 & 0.132 & -1.123 & 0.264 \\
Japanese streetscapes & 740 & 2.42 & 0.625 & -0.612 & 0.090 & -0.573 & 0.179 \\
Japanese daytime str. & 400 & 2.51 & 0.597 & -0.767 & 0.122 & -0.385 & 0.243 \\
Japanese nighttime str. 340 & 2.33 & 0.645 & -0.438 & 0.132 & -0.699 & 0.264 \\
\hline
\end{tabular}

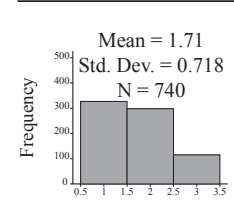

(a) Algerian streetscapes

Mean $=2.42$

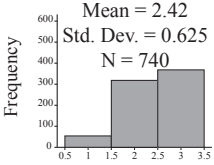

(b) Japanese streetscapes

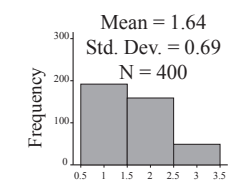

(c) Algerian daytime str.

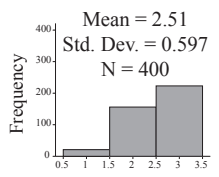

(d) Japanese daytime str.

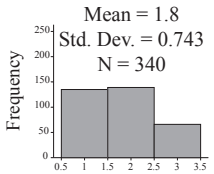

(e) Algerian nighttime str.

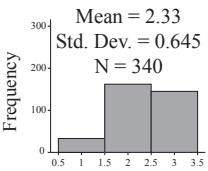

(f) Japanese nighttime str.
Fig. 9 Complexity histograms of Algerian and Japanese sample streetscapes

\subsection{Cognitive clustering}

The descriptive statistical analysis of the data helped in checking the variables and understanding the characteristics of the collected results. Evaluation analysis of human tendency using SPSS 11.0 software was applied to analyze the 3-point scale clustering done by the participants. Principal axis factoring with Varimax rotation was the selected method for factor analysis in order to analyze the factorial structure of the cognitive appraisal. Cluster analysis using Ward method helped in classifying the resulting items scoring into different clusters related to their subjective complexity. Factor loadings are shown in table 4 . These loadings are listed in a descending order according to each factor. The eigenvalues of the first, second and third factors were $10.58,1.60$ and 1.17 respectively, reflecting $66.77 \%$ of variance. For participants, these three factors were labeled as follows:

(i) Factor I, was labeled: "Japanese architectural students / Algerian architectural practitioners" (60\% Japanese, 40\% Algerian).

(ii) Factor II, was labeled: "Architectural students" (65\% Japanese, 35\% Algerian).

(iii) Factor III, was labeled: "Algerian architectural practitioners" (100\% Algerian).

For streetscapes, factor I was labeled as the "Crowdedness-Vegetation" factor. 
Complexity in this factor was reflected through the high amounts of vegetation, people, vehicles and cluttered elements (Fig. 10 \& 11).

Factor II was labeled as the "Congestion-Vegetation-Modernity-Clutter" factor. Complexity in this factor was reflected through buildings modernity and the high amounts of vegetation, people, modern and cluttered elements (Fig. $12 \& 13$ ).

Factor III was labeled the "Darkness-Vegetation-Clutter" factor. Complexity within this factor was related to darkness in nighttime and depended upon the higher amounts of vegetation and cluttered elements (Fig. 14 \& 15).

Table 4 Results of factor Analysis (after Varimax rotation)

\begin{tabular}{|c|c|c|c|c|c|c|c|}
\hline Variables & Factors I & Factors II & Factors III & Communalities & 1 & 2 & 3 \\
\hline AM1 & 0.84 & 0.27 & 0.07 & 0.82 & & & \\
\hline AF1 & 0.81 & 0.22 & 0.37 & 0.85 & & & \\
\hline JM1 & 0.59 & 0.53 & 0.21 & 0.73 & & & \\
\hline $\mathrm{JF} 1$ & 0.58 & 0.36 & 0.26 & 0.67 & & & \\
\hline AM2 & 0.55 & 0.31 & 0.48 & 0.73 & & & \\
\hline JF2 & 0.55 & 0.47 & 0.24 & 0.67 & & & \\
\hline $\mathrm{JF} 3$ & 0.53 & 0.41 & 0.35 & 0.72 & & & \\
\hline JF4 & 0.50 & 0.29 & 0.26 & 0.50 & & & \\
\hline JM2 & 0.47 & 0.34 & 0.42 & 0.65 & & & \\
\hline JF5 & 0.16 & 0.81 & 0.09 & 0.60 & & & \\
\hline JM3 & 0.42 & 0.67 & 0.28 & 0.77 & & & \\
\hline JF6 & 0.41 & 0.62 & -0.01 & 0.66 & & & \\
\hline JM4 & 0.23 & 0.59 & 0.36 & 0.59 & & & \\
\hline AM3 & 0.30 & 0.50 & 0.44 & 0.65 & & & \\
\hline $\mathrm{AF} 2$ & 0.15 & 0.38 & 0.18 & 0.34 & & & \\
\hline AF3 & 0.28 & 0.15 & 0.69 & 0.63 & & & \\
\hline AM4 & 0.52 & 0.25 & 0.67 & 0.83 & & & \\
\hline AM5 & 0.51 & 0.28 & 0.65 & 0.83 & & & \\
\hline $\mathrm{AF} 4$ & 0.00 & 0.08 & 0.65 & 0.48 & & & \\
\hline AM6 & 0.53 & 0.31 & 0.58 & 0.83 & & & - $1-1$ \\
\hline Eigenvalue & 10.58 & 1.60 & 1.16 & $\frac{\text { Extraction Method }}{\text { Principal Axis }}$ & \multirow{3}{*}{\multicolumn{3}{|c|}{$\begin{array}{l}\text { JM Japanese Male } \\
\text { JF Japanese Female } \\
\text { AM Algerian Male } \\
\text { AF Algerian Female } \\
\bullet-\text { Algerian streetscapes } \\
\ldots \text { Japanese streetscapes }\end{array}$}} \\
\hline$\%$ of Variance & 52.92 & 8.02 & 5.83 & $\begin{array}{c}\text { Factoring. } \\
\text { Rotation Method }\end{array}$ & & & \\
\hline$\underset{\%}{\text { Cumulative }}$ & 52.92 & 60.94 & 66.77 & $\begin{array}{l}\text { Varimax with Kaiser } \\
\text { Normalization }\end{array}$ & & & \\
\hline
\end{tabular}

\subsection{Cognitive ranking}

After gathering the ranked data from the participants, it was necessary to represent the divisions among simple, ordinary and complex categories. These divisions could be identified by including two more imaginary items, with additional ranking positions that represent two axes of separation within the dataset. For example, if the simple group contained ten streetscapes, the division between simple and ordinary categories occupies the $11^{\text {th }}$ position in the ranking. The ranking positions " $i$ " (where $i=1,2, \ldots, 76$ ) were scaled down to $c$-scores " $c(i)$ ".

$$
c(i)=2 . \frac{i-38.5}{22}+5
$$

The final rank $r$ of each picture was calculated on the basis of its average positioning

$$
r=\frac{1}{3} \sum_{i}^{76}\left[v_{i} \cdot c(i)\right]
$$

Where $v_{i}$ is the number of times a specific image was located by the participants at a position $i$

Figure 16 exhibits the range of $r$-values for each streetscape category, based on the ranking of all participants.

The category of simple streetscapes consists of 15 Algerian streetscapes (nine daytime and six nighttime streetscapes). The category of ordinary streetscapes includes 43 images (20 Algerian and 23 Japanese streetscapes; among them 20 were daytime streetscapes and 23 were nighttime streetscapes). The

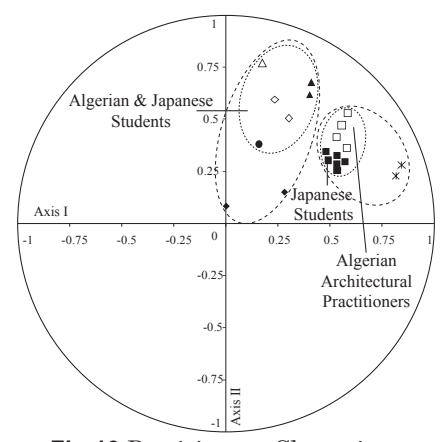

Fig.10 Participants Clustering ( Factor I\& II)

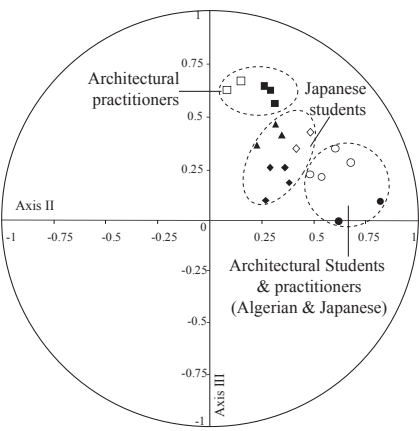

Fig.12 Participants Clustering ( Factor II\& III)

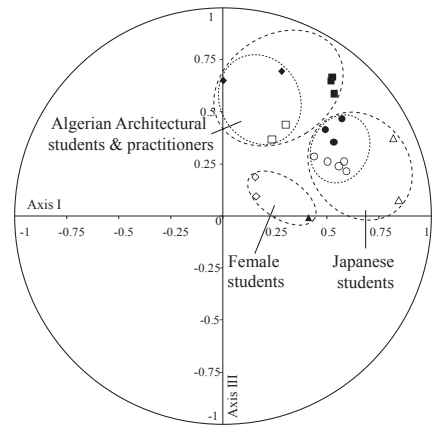

Fig.14 Participants Clustering ( Factor I\& III)

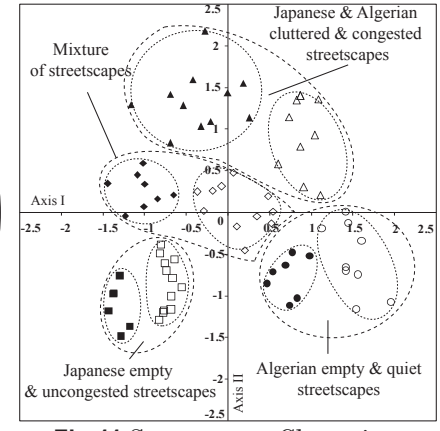

Fig.11 Streetscapes Clustering ( Factor I \& II)

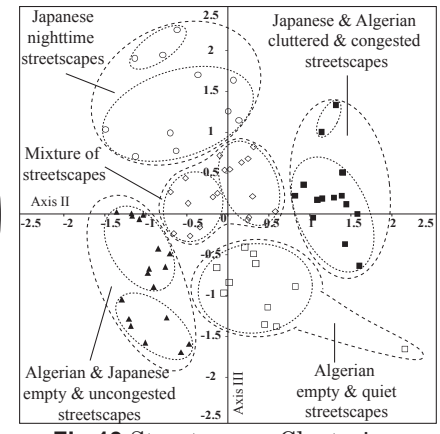

Fig.13 Streetscapes Clustering ( Factor II \& III)

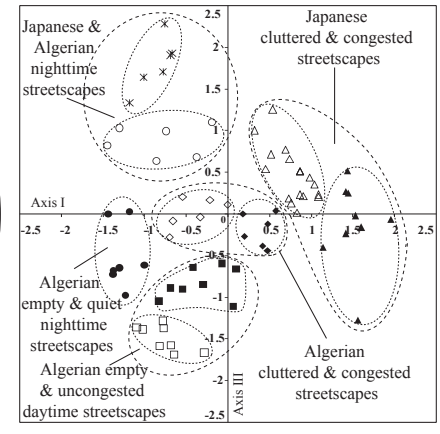

Fig.15 Streetscapes Clustering ( Factor I \& III)

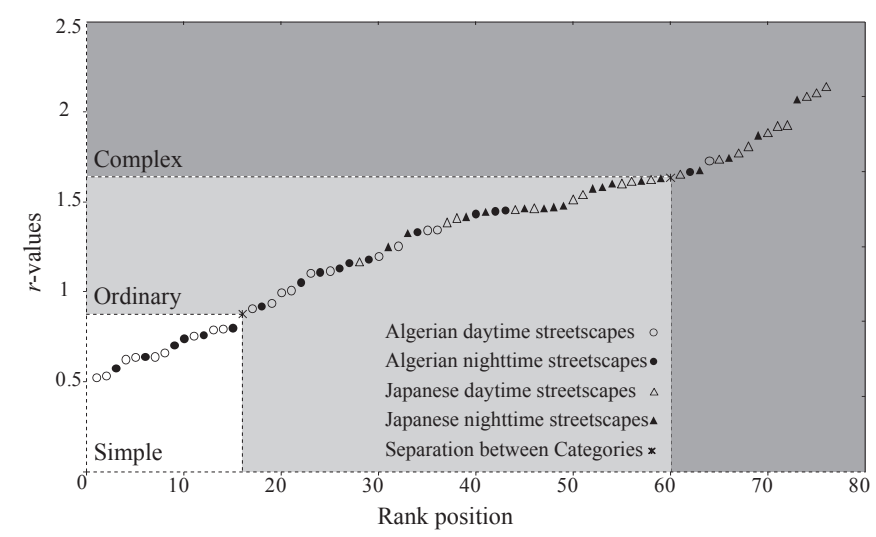

Fig.16 Cognitive ranking analysis for all participants

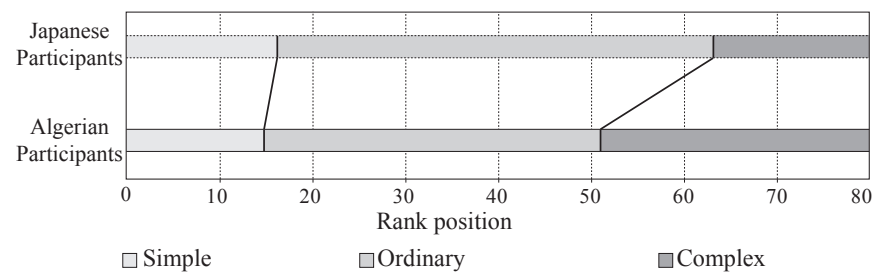

Fig.17 Ranking Differences between Algerian \& Japanese participants 
category of complex streetscapes covered 16 images (Two Algerian and 14 Japanese streetscapes; among them 11 were daytime streetscapes and five were nighttime streetscapes).

Algerian streetscapes dominate the low level of the rating scale, in which they represent the entire simple category and the lower part of the ordinary category. Japanese streetscapes dominate the higher level of the rating scale, in which they represent the major part of the complex group and the higher part of the ordinary group.

After analyzing the ranking positions attributed by Japanese and Algerian participants separately, the ranking done by Algerian participants showed higher sensitivity to complexity (Fig. 17). The correlation between the two rankings had a high correlation coefficient of $\mathrm{R}=0.90$.

\section{RMS contrast and visual complexity}

\subsection{Image preprocessing}

Images were transformed from color scales to grayscales and resampled to $1072 \times 712$ pixels because color images are complicated and hard to process whereas contrast can be efficiently estimated using grayscale images. A "gray" color is the one in which red, green and blue components all have equal intensity in RGB space. Grayscale images are entirely sufficient for many tasks because less information needs to be provided for each pixel. It is only necessary to specify a single intensity value for each pixel, as opposed to three intensities needed to specify each pixel in a full color image.

\subsection{Measurement of image contrast}

Human capacity to discern information includes the ability to perceive differences in luminance within a field of vision. This creates different patterns of contrast that provide visual information to the viewer. Large objects require less sensitivity to contrast while detailed objects require much more sensitivity.

The definition of image contrast depends on its application, which led to various methods of contrast measurement. These measures include: simple contrast, Weber contrast, Michelson contrast and RMS (root-mean-square) contrast. Basically, contrast is the difference in luminance that helps in distinguishing the representation of an image. Simple contrast is defined as the ratio between maximum luminance $\left(\mathrm{L}_{\max }\right)$ and minimum luminance ( $\left.\mathrm{L}_{\min }\right)$ :

$$
C_{\text {simple }}=\frac{L_{\max }}{L_{\min }}
$$

Weber contrast is defined as the ratio between the difference of luminance and minimum luminance:

$$
C_{\text {weber }}=\frac{L_{\max }-L_{\min }}{L_{\min }}
$$

Weber contrast can be considered as the most basic of contrast measures. It is applied for spots and letters and used to compare the luminance of relatively small foreground objects to the luminance of a homogenous background. The disadvantages of Weber contrast are: (1) its computation that requires the segmentation of the image. (2) It is based on the assumption that the background has a uniform luminance, which is not always true.
Michelson contrast defines contrast using a summary of both background and target luminance, designated as maximum and minimum luminance values. It is expressed as:

$$
\begin{gathered}
C_{\text {Michelson }}=\frac{L_{\max }-L_{\min }}{L_{\max }+L_{\min }}=\frac{1}{2} \frac{L_{\max }-L_{\min }}{\mu_{I}} \\
L_{\max }: \text { maximum luminance } \\
L_{\max }: \text { minimum luminance } \\
\mu_{I}: \text { the mean luminance }
\end{gathered}
$$

Michelson contrast is applied for patterns where both bright and dark features cover similar fractions of the image. Michelson contrast is generally appropriate for stimuli such as sine wave that modulates luminance symmetrically above and below the mean, which is not correct for the data used in this study.

\subsubsection{RMS contrast}

RMS (root mean square) contrast is defined as the standard deviation of pixel intensities, commonly applied for non-periodic targets (noise, textures and images $)^{18,19)}$. In a study of natural images contrast, Levien found that RMS contrast model was the most reliable indicator of visible images ${ }^{17)}$. RMS contrast does not depend on spatial frequency content neither on spatial distribution of contrast within an image and represents the most commonly used measure to quantify image details in image processing systems as well as a good predictor of the subjective/apparent contrasts of compound grating images and random noise patterns ${ }^{20)}$.

In this study, let us consider around every pixel $\mathbf{I}(i, j)$ of the input image, a neighborhood of $2 \mathrm{~N}$ x $2 \mathrm{~N}$ pixels denoted by a vector $\mathrm{n}$. $\sigma_{n}$ represents the RMS contrast of luminance, which is the standard deviation of luminance values in a neighborhood $\mathbf{n}$ (Fig.18). For all possible locations $(i, j)$, the respective $\mathbf{n}$ is processed by a workflow. Then, a contrast map $\mathbf{C}$ is built, so that each value $\mathbf{C}(i, j)$ is the RMS contrast of $\mathbf{n}$.

$$
\sigma_{n}=\sqrt{\frac{1}{4 L^{2}} \sum_{i=1}^{4 L^{2}}\left(n_{i}-\bar{n}\right)^{2}}
$$

$$
\begin{aligned}
& \sigma_{n} \text { represents the RMS contrast of luminance } \\
& n_{i} \text { represents one pixel inside the neighborhood } \mathbf{n} ; \\
& \bar{n} \text { is the mean value of } \mathbf{n} .
\end{aligned}
$$

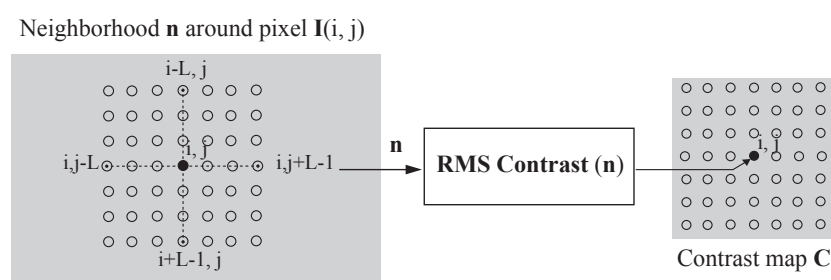

Fig. 18 Block diagram of the physical measure.

\subsection{Measure of visual complexity $\alpha$}

By considering a specific pixel $\mathbf{I}(i, j)$ and its respective $\mathbf{n}$, the contrast map C is calculated as:

$$
C(i, j)=\sigma_{n}
$$


The proposed measure of visual complexity was based on the statistical analysis of contrast distribution within each streetscape image. For an objective appraisal of visual complexity $\alpha$, this study defines $\alpha$ as the mathematical product of the mean value of a neighborhood $\mathrm{n}$ and the standard deviation of pixel intensities:

$$
\alpha=\mu_{c} \cdot \sigma_{c}
$$

$$
\alpha \text { : visual complexity; }
$$

$\mu_{c}$ : mean of RMS contrast values $\mathbf{C}(i, j)$;

$\sigma_{c}$ : standard deviation of RMS contrast values $\mathbf{C}(i, j)$.

\section{Results and discussion}

Figure 19 shows examples of contrast maps of three streetscape images. The image in the top was ranked as the most simple. The image in the middle was ranked as ordinary and the bottom image was ranked as the most complex. Figure 19.a represents the original images. Figure 19.b represents their respective contrast maps and figure 19.c shows their respective histograms. In contrast maps, sharp changes of luminance receive very high values, which highlight features such as image contours. The differences between contrast maps were quantified using their histograms. Figure 20 shows how visual complexity $\alpha$ correlates with cognitive rankings given by $r$-values of Algerian and Japanese participants. For example, plot 20.a shows the correlation coefficient between $\alpha$-parameter and $r$-values for all participants $(\mathrm{R}=0.57)$. Plot 20.b shows the correlation coefficient between $\alpha$-parameter and $r$-values for Japanese participants $(\mathrm{R}=0.61)$ and plot $20 . \mathrm{c}$ shows the one for Algerian participants $(\mathrm{R}=0.50)$. Compared to daytime streetscapes, most of nighttime streetscapes had lower mean contrast because of the lack of light (Plot 20.d, 20.e, 20.f, 20.g, 20.h \& 20.i) and (Tab.5). Since several nightscapes had high $r$-values, humans do not seem to judge their visual complexity only on the basis of parameters derived from contrast

(a) Original scene

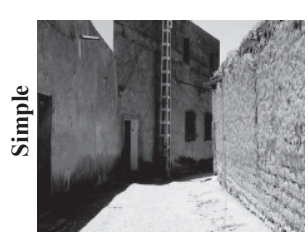

(b) Contrast map $\mathbf{C}$

(c) Histogram of $\mathbf{C}$

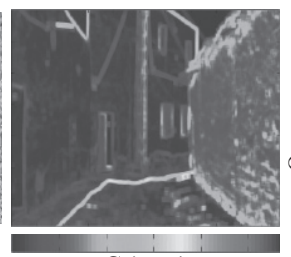

$\mathbf{C}(i, j)$
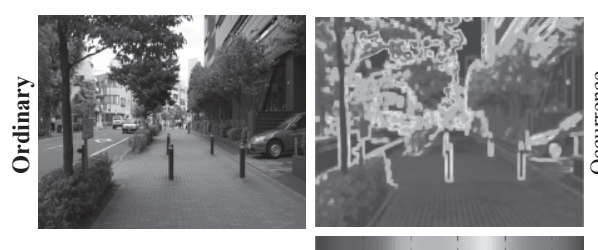

$\mathbf{C}(i, j)$
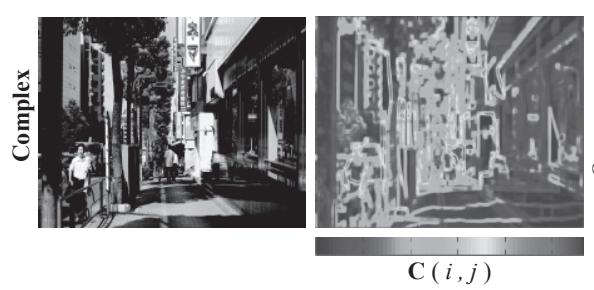

Fig. 19 Statistics of contrast maps

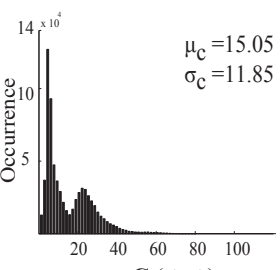

$\mathbf{C}(i, j)$

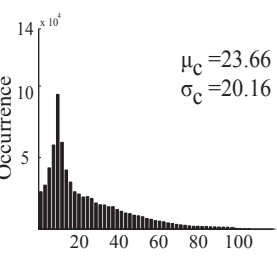

C $(i, j)$

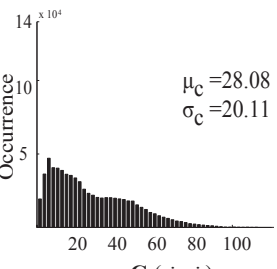

$\mathbf{C}(i, j)$

Table 5 Correlation coefficients between complexity measure $\alpha$ and subjective rankings $r$-values

\begin{tabular}{lccc}
\hline & $\begin{array}{c}\text { All } \\
\text { participants }\end{array}$ & $\begin{array}{c}\text { Japanese } \\
\text { participants }\end{array}$ & $\begin{array}{c}\text { Algerian } \\
\text { participants }\end{array}$ \\
\hline Algerian streetscapes & 0.27 & 0.39 & 0.08 \\
Japanese streetscapes & $\mathbf{0 . 5 7}$ & $\mathbf{0 . 6 0}$ & 0.48 \\
Daytime streetscapes & $\mathbf{0 . 8 3}$ & $\mathbf{0 . 8 0}$ & $\mathbf{0 . 8 4}$ \\
Nighttime streetscapes & $\mathbf{0 . 5 1}$ & $\mathbf{0 . 5 5}$ & 0.42 \\
All streetscapes & $\mathbf{0 . 5 1}$ & $\mathbf{0 . 6 1}$ & $\mathbf{0 . 5 0}$ \\
\hline
\end{tabular}

(a) All Participants, All streetscapes

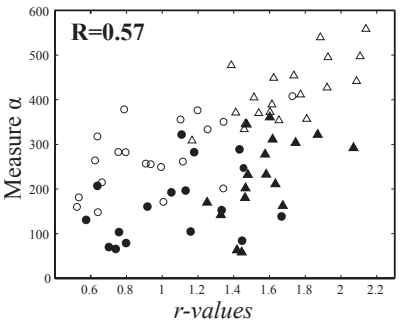

(c) Algerian Participants, All streetscapes

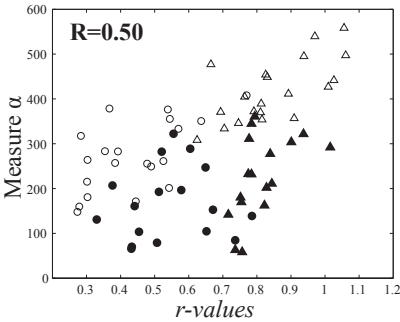

(e) Japanese Participants, Daytime streetscapes (f) Algerian Participants, Daytime streetscapes
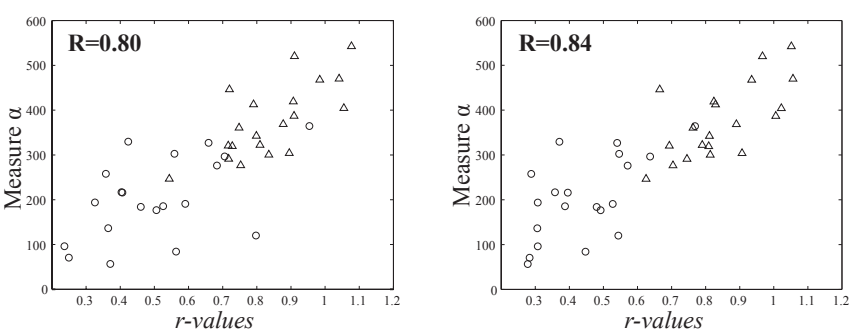

(g) All Participants, Nighttime streetscapes
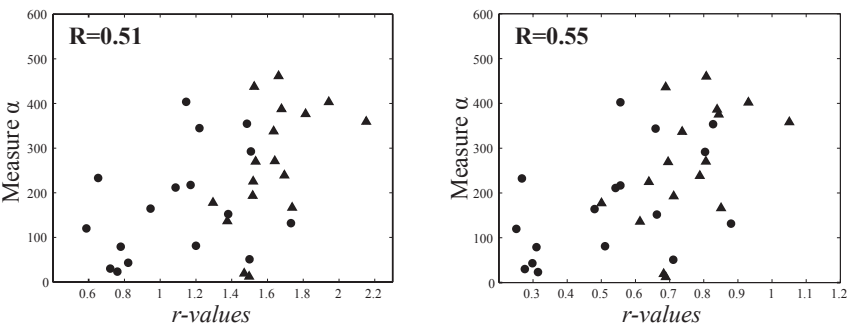

(i) Algerian Participants, Nighttime streetscapes

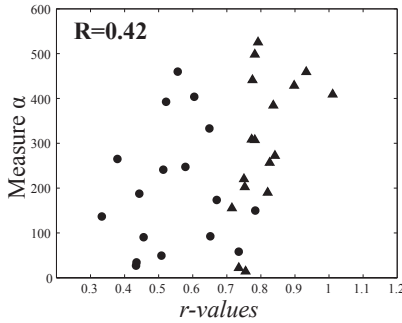

- Algerian daytime streetscapes

- Algerian nighttime streetscapes

$\triangle$ Japanese daytime streetscapes

$\Delta$ Japanese nighttime streetscapes

Fig. 20 Correlation between $\alpha$ and $r$-values 
Perceived complexity is likely to increase as the number of high-contrast features increases. The mean $\mu_{c}$ positively correlates with the subjective ranking of complexity of each streetscape image. It varied from 15.05 (for the most simple streetscape image) to 28.08 (for the most complex streetscape). Standard deviation $\sigma_{c}$ is a measure of contrast variety within the visual composition. It increases with the presence of features that generate $\mathbf{C}(i, j)$ values, either higher or lower than $\mu_{c}$. Interestingly, the proposed measure does not use information about color distribution, which is likely to have an important influence on the judgments of participants.

\section{Conclusion}

Visual complexity represents a delicate and multifaceted concept because of its dependence on many different factors. Perceiving complexity strongly influences the affective appraisal of visual compositions. Nevertheless, how people perceive complexity in the surrounding environment is still yet to be understood.

The present study tried to introduce a novel approach to estimate and measure visual complexity in streetscapes using RMS contrast information. Visual complexity " $\alpha$ " is expressed throughout this paper as the product of contrast mean and its standard deviation. The findings of this research could reflect a positive correlation between the complexity ranking of streetscape images and their visual complexity. This correlation was high in daytime and moderate in nighttime. Furthermore, Algerian participants showed higher sensitivity to complexity compared to Japanese participants. This is due to their familiarity with the simplicity that characterizes Algerian streetscapes compared to Japanese streetscapes.

It is important to mention the limitations of this study. First, this study could only cover four cities in Japan and Algeria, because of many constraints related to time limits and lack of resources. Second, this study covered only one view position from the sidewalk. And third, the proposed measure of visual complexity did not take into consideration other psychological variables such as familiarity.

Authors believe that studying streetscape images taken from different visual points, and the use of different psychophysiological methods such as brainwave analysis would open the boundaries of this research towards new perspectives. Taking into account different physical features such as fractal dimension might help in discovering some hidden aspects of visual complexity in streetscapes.

\section{References}

1) Celik Z. et al.: Streets: Critical Perspectives on Public Space, university of California press, 1994

2) Krier R.: Urban space, Academy editions, 1979

3) Rapoport A.: Pedestrian street use: Culture and perception, Aesthetics and psychobiology, New York, Van Nostrand Reinhold Company, pp. 80-92, 1987

4) Côte, M.: L'Algérie ou l'Espace retourné, Constantine, Édition Média plus, 1993

5) Ashihara Y.: The Aesthetic Townscape, Translate by: E. Riggs L., MIT press, Cambridge London, 1983

6) Cullen G.: Townscape, Architectural Press, London, 1961

7) Messinger, S. M.: Pleasure and complexity: Berlyne revisited. The Journal of Psychology, 132, pp. 558-560, 1998

8) Nasar, J.: What design for a presidential library? Complexity, typicality, order and historical significance, Empirical Studies of the Arts, 20, pp.83-99, 2002
9) Osborne, J. W., \& Farley, F. H.: The relationship between aesthetic preference and visual complexity in abstract art, Psychonomic Science, Vol. 19, pp. 69-70, 1970

10) Stamps, A. E., III.: Entropy, visual diversity, and preference, The Journal of General Psychology, Vol.129, pp.300-320, 2002

11) Berlyne, D. E., Ogilvie, J. C., \& Parham, L. C. C.: The dimensionality of visual complexity, interestingness, and pleasingness. Canadian Journal of Psychology, 22, pp. 376-387, 1968

12) Hall, A. C.: Measures of the complexity of random black and white and colored stimuli. Perceptual and Motor Skills, 29, pp. 773-774, 1969

13) Nicki, R. M.: Arousal increment and degree of complexity as incentive. British Journal of Psychology, 63, pp. 165-171, 1972

14) Matsumoto N., Teranishi N. \& Senda M.: Studies on factors of disorder and regularity in the street view: Studies on disorder and regularity in the central business district -Part 1-, Journal of architecture, planning and environmental engineering, No. 429, pp. 73-82, 1991

15) Seta S, Matsumoto N, Tanabe J.: A study on usefulness of Fourier Transform Method for Evaluating Streetscapes, Journal of architecture, planning and environmental engineering, No. 569, pp. 85-92, 2003

16) Mansouri A., Matsumoto N.: Study of entropy as a background of complexity in the visual composition of daytime streetscapes in Algeria and Japan, proceeding of the 8th International Symposium on Architecture in Asia, AIJ, Kitakyushu, pp. 1201-1204, 2010

17) Levien, R.: Resolution-Dependence of Perceived Contrast of Textures, http://www.levien.com/artofcode/ei04/contrast.pdf [2012-09-10]

18) Frazor, R.A., Geisler, W.S.: Local luminance and contrast in natural images, Vision Research, vol. 46, pp.1585-1598, 2006

19) Bex P.J. et al.: Contrast sensitivity in natural scenes depends on edge as well as spatial frequency structure, Journal of Vision, vol. 9(10):1, pp.1-19, 2009

20) Moulden B., Kingdom F., Gatley L F.: The standard deviation of luminance as a metric for contrast in random-dot images, Perception 19(1), pp. 79-101, 1990

\section{和文要約}

本研究は、日本とアルジェリアの街路景観を構成する視覚的複雑 性の認識的側面及び物理的な特徴の比較を目的とする。

研究の手順は次の通りである。

（1）日本とアルジェリアの街路40箇所（日本：20箇所、アルジェ リア：20箇所）において、74枚の写真を収集した。期間は、2010年6 月から8月である。評価は複雑性を尺度化して三段階評定を行った。

（2）評価実験は、まず、2011年9月に日本人 10 人を対象として、日 本で実施した。次に、 2011 年 12 月にアルジェリア人 10 人を対象とし て、アルジェリアで実施した。

（3）分析は、認識的側面及び物理的な特徵を得るために、

（i）認識的側面については、被験者がイメージする視覚的複雑 性についての心理量分析を行い、分析手法として順位法、クラスタ 分析、因子分析を用いた。

（ii）物理的な特徴については、Root-Mean-Square： RMS（二乗 平均平方根コントラスト解析）を行った。

以上より、以下の結果を得た。昼間の街路景観では、認識的側面 と物理的な特徴は強い相関（ $r=0.83 ）$ 関係にある。一方、夜間の街 路景観では、すべての被験者にとって、認識的側面と物理的な特徵 との相関（r=0.51）はやや低くなっている。また、アルジェリア人 の視覚的複雑性の評価範囲（分散）は、日本人の被験者よりも大き い。しかし、日本人の複雑性に関する認識的側面と街路の物理的な 特徵との相関係数は、0.55〜0.80となっており、比較的大きい相関 を示している。 